\title{
HaRM, COMmunity TOLERANCE, AND THE INDECENT: A Discussion of R. v. MARA
}

\section{ANNALISE ACORN}

\section{INTRODUCTION}

Pornography is no longer "sexy" in the academy. Neither feminist nor other scholars show much interest in continuing to theorize the law's role in regulating the sexually explicit. Most of the familiar stakeholders in the debate - free speech liberals, radical feminists, lesbian and gay activists, and moral majoritarians - seem to have nothing new and little left to say on the subject. Emotions, once fiery, have run their course. Thus, it is not surprising that the decision of the Supreme Court of Canada in $R$ v. Mara, dealing with the substance of the Criminal Code prohibitions against indecency in the context of night club performances, has not been the occasion of much discussion. The Mara decision supposedly draws on the Supreme Court's decision in $R$. v. Butler, ${ }^{2}$ where the substance of the offence of obscenity was defined with reference to feminist analysis of the harms of pornography. In the aftermath of Butler, however, feminist response to legal developments in the area reveal nothing of a continued passionate engagement with the issue but rather are characterized by boredom, exasperation and a preference for looking the other way.

Yet the Mara decision highlights a disturbing aspect of law: ideas - once lodged in the text of the law - legitimate and facilitate the exercise of power long after those ideas have lost their sparkle in the eyes of intellectuals. Law as an academic discipline and as a social practice consistently requires one to remain engaged with the past, however unfashionable and embarrassing old ideas may now be. If a fragment of intelligence secures a legal incarnation it can surpass its own natural life span by centuries. The longevity of ideas embedded in law should always be of concern to those who seek to influence law's development. It should particularly be of concern to feminists who are only now achieving any real presence in legal institutions and are beginning to reach some reasonable level of participation in the shaping of legal constructs.

The feminist analysis of the harms of pornography argued by the Women's Legal Education and Action Fund (LEAF) and adopted in the landmark decision of $R$. $v$. Butler, while purportedly forming the foundation of the decision in Mara, is in fact completely absent in any woman-centred form. Mara, an appeal from a decision of the Ontario Court of Appeal, ${ }^{3}$ was heard by seven members of the Supreme Court. The case dealt primarily with the substance of the prohibition of indecency found in $\mathbf{s}$.

Associate Professor, Faculty of Law, University of Alberta. I would like to thank Colin Feasby for the suggestion to write on this case and for the idea of juxtaposing the reasoning in Mara with that in Jacob, infra at note 24.

[1997] S.C.J. No. 29 (QL) [hereinafter Mara].

[1992] 1 S.C.R. 452 [hereinafter Butler].

(1996), 27 O.R. (3d) 643. 
167(1) of the Criminal Code. The performance which formed the subject matter of the charge was a "table dance" which involved sexual contact between dancers and audience members. The judgment of the Court was delivered by Sopinka J. who, interestingly, also delivered the judgment of the majority in Butler.

Much of the case is given over to the analysis of two issues collateral to the question of the substance of the standard of indecency found in s. 167(1) of the Criminal Code. The first collateral issue was whether the trial judge's ruling that the performance in question had not exceeded the community standard of tolerance (and was hence not indecent under 167(1)) was a matter of fact or law. The appellants argued this was a finding of fact not amenable to appellate review and thus that the Ontario Court of Appeal lacked jurisdiction to overturn the trial judge's decision on this point. The Supreme Court found that while the substance of the standard of indecency was a determination to be made in light of a factual context it was, nevertheless, a matter of law and was therefore subject to review on appeal. ${ }^{4}$ The second collateral question the Court dealt with also revolved around the fact/law distinction and the appropriate scope of appellate review. Here the Court considered the question of whether the trial judge's finding that the appellant Mara, who was the owner of a night club in which the allegedly indecent performances took place, did not have the necessary criminal intent to support a finding of guilt was a matter of fact or law. Here the Court held that the question of the appellant Mara's intent was a question of fact and therefore, ought not to have been subject to review by the Ontario Court of Appeal.

The rest of the decision dealt with the substance of the prohibition of indecency found in s. 167(1) of the Criminal Code. In dealing with the decision I will not deal with either collateral issue. Rather, this comment concerns the Court's analysis of the substance of indecency. Further, the focus of this critique of the Mara decision will be primarily on the gaps or silences in the Court's reasoning. The problem with the Mara decision is the absence of women's statements, views, theories or experience in the Court's analysis of the question of whether the performances in question were harmful to women. It will be argued that Sopinka J.'s judgment in this case retains nothing of the commitment promised in Butler to engage in genuine discussion and evaluation of the question of whether that which is sexually explicit is also harmful to women.

No feminist or female voice is heard anywhere in the Mara decision and the substance of the standard for determining indecency is essentially decided with reference to a highly conservative, patently male-centred conception of what was wrong with the performance in question. The Court explicitly rejects reliance on actual harm to women performers and finds that this concern is irrelevant to the substance of the standard of indecency. ${ }^{5}$ Further, the Court neglects to give any real explanation for its conclusion that the performances were such as to cause "attitudinal harm on those watching the performance." 6 The most direct formulation of the Court's reasoning in coming to the conclusion that the performance exceeded the community standard of 
tolerance is seen in Sopinka J.'s statement that: "In effect, men, along with drinks, could pay for a public, sexual experience for their own gratification and those of others. In my view such activities gave rise to a social harm that indicates that the performances were indecent." experience in question were taken to be self-evidently harmful. This conclusion, I would argue, is a troubling one. It is, I would suggest, more driven by a traditional abhorrence of the commercialization of the sexual than it is with the question of whether - in the circumstances of the case - that commercialization is in fact harmful, dehumanizing, or degrading to women. It is concerned with keeping orthodox boundaries of the private in place and is more driven by an abhorrence of the "publicization" of the private than it is by a concern with the equality analysis set out in Butler.

The issue of the substance of indecency is clearly no longer on the LEAF agenda and it was entirely predictable that LEAF would not intervene in the Mara case. However, the jarring fact is, even though this issue is passe among feminists, the Courts continue to give content to the legal categories of obscenity and indecency and in the absence of feminist intervention that content is persistently more geared toward solidifying traditional conceptions of "proper" sexual behaviour. What is worse is that Mara creates a new strategy wherein the traditional practice of male regulation of female sexuality is camouflaged or rather tarted-up in pseudo-feminist clothing. Sopinka J. uses the language of dehumanization and degradation which he adopted from the LEAF factum in his decision in Butler. In Mara, however, we do not see any real attempt to locate the question of the legality of commercial and public sex within an analysis of harm to women. The Court demonstrates a fundamental unwillingness to delve into the question of exactly why this performance should be understood as dehumanizing, degrading, or harmful. Rather than seeing even an interest in whether women experience such performances as harmful, degrading or dehumanizing; rather than seeing an engagement with the question of the sorts of attitudes that the performance purportedly instilled in the audience; we see a conservative consolidation of power and authority over women's sexuality. The Court legitimates and enforces the status quo by reference to what was - only a short time ago - radical feminist theory. In short: the tools of the oppressed proved to be remarkably useful in the project of refurbishing the master's house.

\section{MaRA AND BlISS: The New SENSITIVE BaCKLASH}

Reading the decision in $R$. v. Mara gave me the same queasy feeling I had while watching the film Bliss. A peculiar comparison perhaps, but ultimately I think that Bliss and Mara are two examples of a single rhetorical phenomenon. In Bliss, written and directed by Lance Young, Joseph, a doting husband (played by Craig Sheffer), discovers that his infantile and self-absorbed wife Maria (played by Sheryl Lee) is having sex with her therapist Baltazar (played by Terence Stamp) as part of her "healing process." Joseph, consumed by a turbulent mix of paternalistic protectiveness and outraged jealousy, confronts the therapist in a fit of rage and desperation. The 
therapist, predictably undaunted by Joseph's emotions, calmly offers him tea, sympathy, and a space to express feelings.

Eventually, Joseph is drawn into Baltazar's serene charisma and the two men enter into an accord. The therapist agrees to stop having sex with the wife and to assist the husband in cultivating the necessary technique, stamina, and sensitivity to satisfy her. Exactly what the husband offers as consideration for the bargain is unclear. However, it appears at least to be forbearance from reporting the therapist's unprofessional methods which, to the husband's knowledge, included sadomasochistic sex with one of his clients supposedly in an effort to cure her of her desire for abuse. The two men pool their resources - Joseph: brawn, love, and legitimate title to his wife's sexuality; Baltazar: brains and the secret keys to unlock her - and they embark together on a journey of discovery, strategy and exploration.

The film proceeds with a number of sex scenes between Joseph and Maria. But for one moment of vicious sexual aggression by Maria, the duality of feminine prone passivity and masculine beneficent agency is drawn in stark contrast. During the course of one of these scenes Maria discovers that she is a victim of child sexual abuse. Her mind is flooded with repressed memories of intercourse with her father. It is at the point of the discovery of her sexual abuse that the film takes on its most subtly sinister character. As Maria remains naked, passive, vulnerable, inarticulate, and almost animallike, the two men, in responding to the challenges of this new glitch in their project, begin to engage in sophisticated and erudite dialogue about the tragic effects of the child sexual abuse and the injustice of women's subordination and disempowerment in Western culture. Baltazar instructs Joseph in the truisms of feminism - engendering in him a sense of sorrow and outrage that patriarchal culture has distorted women into beings willing to sacrifice all aspects of autonomy and self-respect to gain, ever elusive, male approval. Baltazar's lines commingle snippets of feminist thetoric about the pain, betrayal and harm of child sexual abuse with pearls of advice about tantric practises for improving sexual stamina and bringing women to the "ninth level of orgasm." All the while Maria remains absent, mute, naked, vicious, or crazy.

The sex scenes between Joseph and Maria and the tutorial scenes between Balthazar and Joseph are occasionally broken up with scenes demonstrating the side-line occupations of the men. Baltazar gives virtuoso violin performances to adoring audiences in elegant concert halls. Joseph goes off to his equally impressive occupation of supervising the erection of skyscrapers. Maria, in contrast, is rarely seen out of bed. Once, we see her engaged in a pathetic effort to kill imaginary insects she believes have infested her house. We also see her attending her incest support group. There she is puffy-eyed and whimpering, the stark church meeting room bears no resemblance to the lavishly decorated domain of the men.

Notwithstanding all this, Joseph is trapped in the strength of his irrational love for her and he "hangs in" and continues to "show up." In his commitment to her healing and her growth he deepens the bond between them and purportedly helps her to discover her capacity for true intimacy. We are, I think, asked to conclude that it has been a story about the potential depth of men's love for women, the potential tenderness 
of men's empathy for women's violation, and men's willingness and ability to initiate and sustain rich, fulfilling, and sensual connections with women which transcend the pain of women's inequality and exploitation.

So, why does this remind me of the Supreme Court's decision in Mara? The answer is, this film, like the judgment in Mara, was a narrative which, with some subtlety and sophistication, draws on aspects of feminist discourse to present an almost credible and quite seductive facsimile of a woman-centred approach to an issue. Yet both Mara and Bliss erase the significance, and even the existence of the subjectivity, agency, analysis and experience of women. In Bliss the two men theorize a woman's sexuality, appropriating feminist thought to become experts on her: her desire, her pain, her fear, and her boundaries. Their intentions, in some limited sense, are good but their assumption throughout is that they together have the ability, the right, and the duty to think for her and to think her through. Their fluency in the language of feminism legitimates their obliviousness to women's agency and subjectivity.

None of this is meant to suggest that the incorporation of feminist discourse into mainstream discussion of issues is a bad thing. Of course, an essential part of the project of feminism has been to give feminist analysis a place in general cultural understandings of many different issues. However, in circumstances where that incorporation is used to legitimate the papering over of women's experience and the exclusion of women from full participation in the creation of cultural meaning the use of feminist discourse is troubling.

In Mara, we see Sopinka J., speaking for the Court, purporting to use the feminist analysis set out in Butler to further an understanding of the prohibition of "indecency" found in s. 167 of the Criminal Code. However, a quick look at the case immediately reveals that the reasoning is utterly devoid of any genuine engagement with women's experience and women's input on the question of whether the performance is harmful is completely absent. No woman is asked whether the performance was degrading or dehumanizing for her. Nor does the Court engage with the issue of the sexualization of violence which was central to the reasoning in Butler and central to the Court's conclusion that the violation of freedom of expression inherent in the obscenity provisions could be justified under s. 1 of the Charter. The reasoning in Butler was far more specifically directed to the harm of the promotion of hatred of women via a pornographic message portraying women as deserving of punishment, ridicule, violence and abuse in sexual contexts. Likewise, the issue of exploitation of children which was also central to the Court's reasoning in Butler was not referred to or discussed in Mara. The concept of dehumanization and degradation which, in the context of Butler, referred much more explicitly to the violation of individual women and the promotion of hatred toward women, is not brought forward in Mara.

\section{Community Standard of TOlerance and "The Man In Charge"}

Mara dealt with a live performance in a Toronto night club called "Cheaters' Tavern." The trial judge's description of the performance, which was accepted by the Supreme Court as a statement of the relevant facts, was: 
The conduct of each dancer with the customer is clearly detailed in the evidence, and includes (a) being nude, except for wearing an open shirt or blouse; (b) fondling her own breasts, buttocks, thighs, and genitals while close to the customer; (c) sitting on a customer's lap and grinding her bare buttocks into his lap; (d) sitting on a customer's lap, reaching into his crotch and apparently masturbating the customer; (e) permitting the customer to touch and fondle her breasts, buttocks, thighs, and genitals; (f) permitting the customer to kiss, lick and suck their breasts; (g) permitting what appeared to be cunnilingus. ${ }^{8}$

Proceeding on the basis of these facts the court sets out the crucial correlation between indecency and community standard of tolerance now axiomatic in this area of the law. The definition of indecency as a matter of law is to be understood with reference to the national Canadian sensibility. ${ }^{9}$ Further, the relevant sensibility is not what Canadians think is right or wrong for themselves, but what Canadians "would not abide other Canadians seeing" because it would be beyond the contemporary standard of tolerance to allow them to see it. ${ }^{10}$ The substance of this standard is then filled with reference to Butler where the Court finds that the Canadian sensibility on this matter is influenced or even constituted by the radical feminist critique of pornography as a celebration of men's domination and women's subordination - cashed out in a new harm principle that refers to the degradation and dehumanization of women and the fostering of attitudes incompatible with the recognition of men and women as equally deserving of concern and respect. Mara takes the concepts of degradation, dehumanization, and inequality and instead of making a genuine effort to grapple with their meaning, transforms them into a set of "neurotic mantras" - catch phrases whose content is not seriously analysed or considered but which serve as a rhetorical justification for the Court's conclusion. For all the analysis the Court gives to these terms, it may as well have used "dirty," "naughty," and "disgusting" in place of "degrading" and "dehumanizing." An orthodox masculinist discourse which would have been under serious attack by feminists five years ago, now emerges strong and smiling assuming, correctly, that it will not be subject to feminist attack and having benefited immeasurably by its appropriation of feminist discourse.

In Butler there was an attempt to give content to the nebulous concept of "the community standard of tolerance" by reference to feminist thought about how pornography harmed women. The decision in Mara perhaps conclusively reveals this attempt as misguided or even impossible. However, Mara is the culmination of a number of contributing factors. The ambivalence and acrimony among LEAF members and supporters that characterized the aftermath of Butler resulted in a sharp decrease in the feminist commitment to the Butler analysis. While anti-porn feminists had been undaunted by the critiques of heterosexual liberal feminists, they were strongly influenced by the opposition of lesbian feminists who argued persuasively from the

Ibid. at para. 4.

Ibid. at para. 26.

to Towne Cinema Theatres v. R, [1985] I S.C.R. 494 at 500 [hereinafter Towne Cinema], quoted with approval in Mara, supra note 1 at para. 31.

" "Neurotic Mantra" is a term I am borrowing from Charles Taylor. He uses it in relation to the provincial premiers' thetoric around national unity. C.B.C. Radio interview with Charles Taylor, 21 September 1997. 
margin for the protection of a safe creative space in which to explore non-traditional representations of sexuality. This has been perhaps the most powerful force in the sudden deflation of what appeared to be a new, innovative, and truly woman-centred approach to this area of the law in Butler. The prosecutorial targeting of gay and lesbian pornography after Butler, along with the lack of impact the decision has had on the marketing of hard core violent heterosexual pornography, has left many feminists who were previously strong supporters of criminal sanctions in this area feeling chastened, embarrassed and willing to delete pornography from the feminist agenda. So the absence in Mara of women's voices and true feminist engagement with the content of the concepts of dehumanization and degradation on feminist lines is perhaps no surprise and is most likely caused, at least in part, by the actual absence of feminists with a continued interest in explicating an understanding of the way in which the representation of sex and sexuality contribute to and reinforce systemic inequality for women.

Perhaps the most glaring instance of the Court's willingness to approach the notion of degradation and dehumanization with reference to men's understanding and men's experience was the weight that the court placed on the testimony of the accused East, manager of Cheaters' Tavern. Sopinka J. quoted East extensively and with approval:

Q. And for a woman to be masturbating herself in the presence and within view of the male patron, would you consider that to be improper?

A. Improper, whether she was in view or not. Highly improper.

Q. And would that warrant dismissal, as far as you would be concemed?

A. Yes, of course.

Q. And for the patrons to be fondling the breasts of the dancers at Cheaters?

A. If they were to do that also, 1 would eject the customer and the dancer.

Q. Why?

A. Why?

Q. Why? Yes.

A. Because it $-I$ would consider it improper.

Q. And for the dancers to be masturbating the male customers through their clothing?

A. Need you ask? Of course. It would be very improper. Instant total dismissal for life. ${ }^{12}$ 
The Court quotes this part of the transcript in support of the conclusion that the performances were beyond the community's standard of tolerance. The court follows the law's traditional, but dubious, wisdom that statements against self-interest are likely to be true - reasoning that if East himself considered such performances to be improper then they must have exceeded the community's standard. What is offensive here is that, having acknowledged that the standard of community tolerance should be drawn - according to Butler - with reference to the place of sexual representation in the context of systemic devaluation of women, the Court goes on to view the testimony of the accused night club manager as authoritative on that issue. Having initially made reference to the importance of the feminist analysis in Butler, ${ }^{13}$ the Court proceeds to switch its approach completely in supporting its final conclusion. East's testimony clearly is not at all directed toward issues of harm to women, dehumanization or degradation. Nevertheless, the Court takes his evidence as authoritative on the issue of the community standard of tolerance.

In his evidence, East casts himself as the moralistic supervisor of the sexuality of his women employees. Rather than inquiring into whether the women felt exploited, dehumanized or degraded in the production of this entertainment, the Court amplifies the voice of the "man in charge." As East takes on the status of monitor and disciplinarian of the dancers' behaviour and sexuality, and as his perspective is given credence as authoritative on the content of dehumanization and degradation, the concern expressed in Butler for the ways in which pornography damages women in their opportunities and their relationship fades even further into the background. Community tolerance is defined according to patriarchal notions of naughtiness, and with reference to a background assumption that the potential wantonness of women's sexuality is the problem and authoritative male control over women's sexuality is the solution.

An extremely disheartening aspect of the decision, as noted above, is the Court's express holding that actual harm or risk of harm to the performers is irrelevant in determining whether the performance has violated the standard of community tolerance. Sopinka J. writes:

A finding of an indecent performance depends on a finding of harm to the spectators of the performance as perceived by the community as a whole. The potential harm to the performers themselves, while obviously regrettable is not a central consideration under $\mathrm{s} .167 .{ }^{14}$

Thus, the Court disagreed with the Ontario Court of Appeal's finding that the risk of harm to the dancers, the risk of unwanted sexual touching, and the transmission of disease were relevant factors in concluding that the performances were degrading and dehumanizing so as to violate the community standard. Rather than asking specific questions about real harm to the persons involved in the performance, the Court gives content to the notion of social harm by reference to an ill-defined, but seemingly very traditional, understanding of indecency.

$14 \quad$ Ibid. at para. 37. 
Had women performers been consulted on the issue of whether they experienced this sort of performance as degrading, dehumanizing, or harmful it is not clear what they would have said. It is most likely that there would have been a range of opinion on the point. It is not my aim here to speculate about what women would have said had they been heard. Nor do I contend that feminist theory addressing the issues in the case would have been either monolithic or harmonious. Nor is it even my aim to suggest that the outcome of the case was either good or bad. Rather, I want to argue that the way the Court arrived at their conclusions was deplorable given the stated aims of Butler. If nothing else, Butler ought to have at least entrenched some awareness of the importance of giving space and voice to women's experience of sexually explicit performance and representation in the process of ruling on its legality.

\section{Context, Community and Relativism: Not a Moral IsSUe?}

The decision in Mara actually reveals what is an unfortunate consequence of the failure on the part of anti-pornography feminists to ever come to terms with the philosophical foundation of their objections to pornography as it related to the philosophical foundation of the law of obscenity and indecency already in place. I want to suggest that the basic error in feminist argument around pornography was to cast its own position as a utilitarian and relativist one thinking that this distinguished the feminist line from the conservative line on pornography. The conservative view was seen to be deontological and moralistic; stemming from some purportedly true and fixed set of moral beliefs about what constituted the obscene and the indecent. I want to try to demonstrate that the conservative position on obscenity and indecency actually had a far more powerful relativist and utilitarian version and it was this strand that was reflected in and adopted by the law through the community standard test. The failure of Butler to create any lasting difference in the Supreme Court's approach to this area is, in part due to the failure of feminists to distinguish their position from the prevailing conservative, but fundamentally relativist and utilitarian, justifications for the prohibition of the obscenity and indecency.

\section{Distinguishing the Feminist OBJection}

As is well known, feminists opposing pornography and arguing for its criminalization ran up against the unpleasant realization that they were arguing on the side of the enemy. Moral majoritarians and right wing women opposed pornography seemingly alongside radical feminists, and argued with them for tougher criminal sanctions against it. To distance themselves from the traditional "family values" critique of pornography, anti-porn feminists generally took two tacks. The first was to attempt to disclaim that an anti-sex stance was necessarily part of an anti-porn stance, and that it was the "porno" not the "graphic" that was wrong with pornography. Thus, a possibility was left open by anti-porn feminists for valuable erotica that was explicit in its representation of sexuality without being part of a genre of cultural images whose object and effect was the reinforcement of the subordination of women. Just how much such theoretical space remained within radical feminist anti-porn rhetoric is debateable. At times, indeed, those theorists who opposed pornography such as Andrea Dworkin and Catherine MacKinnon could be read as having closed off all logical possibility of 
a conception of the sexual that was not fundamentally grounded in or constituted by masculine coercive power over and violation of the feminine. It was unclear as to exactly which representations or presentations of the body could avoid being categorized as having committed the feminist sin of objectification. Nevertheless, the fine distinction between the pornographic and the erotic was relied on by feminists as placing acres of theoretical space between them and various conservative, fundamentalist opponents of the sexually explicit.

The other tack anti-porn feminists took was to cast the conservative opponents of pornography as concerned with "morality" while they themselves were concerned with "power." This move was strategically wise in intellectual circles since it got feminists out of the unfashionable business of trying to sell particular conceptions of moral truth and put them into the trendier more post-modern business of deconstructing power relations. In her impressive and persuasive piece "Not a Moral Issue"'s Catherine MacKinnon argued that the feminist objection to pornography engages with pornography, not with a view to identifying it as wrong or bad or immoral, but with a view to understanding its cultural role as a tool for keeping social, political, and economic power in the hands of men and out of the hands of women. Thus, MacKinnon argued that women's position of disempowernment and pornography's role in sustaining that position were the justifications for viewing pornography as appropriately prohibited by the criminal law.

While this move was considered astute in academic circles, it was not tactically well considered in legal circles. This is because, while it shifted the justification for using the criminal process to prohibit pornography to a modified or woman-centred utilitarian one - that is, the greatest good for the greatest number of women - it assumed that this did, in fact, create sufficient theoretical space between the conservative position and the feminist position. This was based on a further assumption that the conservative objection to pornography was a deontological one, that is, one which viewed pornography as inherently wrong, sinful, and morally evil. If this were actually true, then a disclaimer of any view about the morality of pornography and a focus on the broader social consequences of pornography to women should have had the desired effect of shifting the feminist position sufficiently far away from the conservative position that an acceptance in the law of the feminist ideas would not risk immediate slippage back to an inquiry of what is and isn't sinful or improper according to the law of God.

What MacKinnon and others did not consider sufficiently carefully was the fact that the existing legal structure of the law of obscenity and indecency was actually already based on a legal theory that was deeply utilitarian and deeply relativist about the substance of what should be considered indecent or obscene. The orthodox justification for the prohibition of obscenity was fundamentally concerned with a loosely defined notion of social harm rather than any inherent immorality of the obscene. Thus, by substituting a new notion of social harm - referring primarily, though not exclusively, to harm to women - the feminist reasoning adopted in Butler failed to sufficiently 
distinguish itself from the old reliance on the disintegration of society as the foundation of the law of obscenity and indecency.

\section{THE ENFORCEMENT OF MORALS AND THE ORTHODOX CONCEPTION OF THE SOCIAL HARMS OF INDECENCY}

In his famous and influential work The Enforcement of Morals ${ }^{16}$ Lord Patrick Devlin argued that the law was justified in making "immoral" conduct criminal even if there was no apparent victim where such conduct was so offensive to the "reasonable man" as to threaten the fabric of society itself. Devlin outlined the relationship between society and shared morality, stating that the latter was a necessary condition of the former. Shared morality, he reasoned, is part of the beneficial bondage of society and is both sustaining and constraining for the individual. Thus, Devlin argued, the basis on which society is justified in prohibiting that which it counts as immoral is its own self-preservation. Shared morality is the glue that holds society together; thus, by legislating to enforce that morality Parliament cements the cohesiveness of the society and works toward guaranteeing its continued existence. Further, the substance of that morality is discovered by reference to the sensibilities of the reasonable man. Those sensibilities relate not only or even primarily to the reasonable man's rational response to things, but rather relate to his emotive and affective or "gut" reactions. ${ }^{17}$ Thus, if the reasonable man is sufficiently shocked, ruffled, or disgusted by the conduct of his fellow members of society that, in and of itself, justifies a prohibition of the conduct.

Devlin's justification for the use of the criminal law in this area is both relativist and utilitarian. It is relativist in the sense that it is indifferent to the content of the category of the "immoral." Thus, Devlin takes no stance on whether or not the conduct in question is actually wrong and this inquiry is outside the logic of his argument. His argument is utilitarian in the sense that the justifying aim he puts forward is the continuation and stability of society - in other words the greatest good of society as a whole. It was this justification for the prohibition of pornography that was influential in the development of the law and not the other conservative and more fundamentalist justification from some purported moral or religious truth about sexual conduct.

The structure of the Canadian law on obscenity and indecency follows the logic of Devlin's argument and neither Butler, for all its revolutionary pretense, nor Mara shift this essential structure. ${ }^{18}$ The analysis in Butler continues to posit the variable and shifting tolerance of the community as being the ultimate arbiter of the scope of what is to be prohibited. Further, the Supreme Court's explication of their understanding of the community standard of tolerance embraces Devlin's concern with the sensibility of the citizen as busybody: it's not what Canadians think is right or wrong, it's what Canadians will not abide others doing or seeing. Thus, the standard is drawn directly with reference to this variable of how shocked or disgusted one person is about what the other person is doing. There is no attempt to analyze the reasoning behind the 
community disgust and, indeed, such an attempt would run counter to the sense of a Devlinian justification. In Devlin's analysis the disgust of the reasonable man is selfjustifying and deserving of respect. ${ }^{19}$

Instead of effecting a necessary break from this form of analysis - fixation on the sensibility of the community as the standard - Butler grafted the notion of harm to women onto the existing referent of the community standard. Rather than jettisoning the argumentative structure of Devlin's justification for the prohibition of the "immoral," the Court preserved it but held that it was to be understood in terms of feminist analysis of pornography that highlights violence, degradation, dehumanization, and the perpetuation of women's inequality as the relevant social harm.

There were a number of obvious difficulties in this reasoning. In the first place, the purported equation of the community standard with feminist ideas about the harms of pornography was obviously factually false. While the feminist position on pornography was gaining ground in popular awareness, it was by no means true that the community standard would ever have anything but a flimsy acquaintance with feminist antipornography theory - let alone that it should have become a part of the average person's gut responses. Thus, the reasoning in Butler was based on a fiction that what the average Canadian wouldn't tolerate in sexually explicit material was the same as what anti-porn feminists would find objectionable.

Secondly, however, the harms identified in the LEAF analysis and in the Court's adoption of LEAF's arguments were never sufficiently distinguished conceptually from the type of social harm that Devlin had been talking about all along. What was not sufficiently clarified or stressed by the Court was that the harm LEAF was trying to identify and make salient was the sort of identifiable harm to individuals that would take the court beyond the need for finding some kind of nebulous social harm understood in terms of anxiety around the disintegration of society. Here the feminist ambivalence toward the type of harm to women they are concerned with is significant: was the concern with harm to individual and identifiable women or were feminists identifying a new species of social harm that could be linked to the orthodox anxiety around the dissolution of shared values. If feminists were concerned, as I think they were, with actual harm to identifiable women then the prohibition of obscenity and indecency could be justified by reference to strongly entrenched liberal ideas that harm to individuals justifies the use of state force to prohibit conduct. The feminist position is ultimately entirely consistent with the liberal position that harm to individuals must be identified before the state has a legitimate justification for exercising coercive force to limit the liberty of the individual. ${ }^{20}$ Once such a harm is identified, the difficulty addressed by Devlin - the search for a legitimate basis on which the state could intervene where no identifiable harm is present - disappears. The feminist contribution then, properly understood, was to expose the nature of the harm of pornography, which

The liberal position is set out in this familiar passage from J.S. Mill, On Liberty (Harmondsworth, U.K.: Penguin, 1976) (1859) at 68: "The only purpose for which power can be rightfully exercised over any member of a civilised community against his will is to prevent harm to others." 
in the past, from a male perspective was invisible, taking it out of the category of victimless or harmless offences which required some other justification for their existence.

What took place, however, was that Devlin's idea of the social harm of disintegration was not sufficiently ousted by the logic of the feminist position. The notion of harm to women, which in its most unmodified form is an exclusionary utilitarianism looking to the greatest good of the greatest number of women - could not have been accepted by the Court: to have cast a notion of public interest exclusively with reference to the well-being of women would have been too radical a choice for the Court to make. Harm to women was, therefore, reconfigured as a new species of social harm. But the Court avoided a more direct and more explicit attempt to identify specific victims of pornography and to place those victims rather than the community standard at the core of the justification of the offence. Thus, the fundamental structure of the law remained in place, and the notion of social dissolution which had long been the foundation of the prohibition on obscenity remained essentially unchallenged. In order to have effected a lasting change in the law the notion of harm to women would have had to have stood on its own as defining the substance of the offence and providing its justification. That possibility was lost when harm to women was rolled into the community standard of tolerance test in Butler.

In Mara, Butler's new improved rendition of social harm regresses back to its Devlinian roots. The Court focuses on the comfort level of the reasonable man and the inquiry into whether there has been harm to identifiable women is rejected as irrelevant. In this case the available spokesperson of reasonable manhood was Mr. East who obligingly articulates the familiar concerns around the social decay that can be caused by permitting the improper. What is exasperating is that all of this analysis had been clearly revealed as spurious as far back as 1963 with H.L.A. Hart's work Law, Liberty and Morality. Hart, with his usual clarity and wit, searingly criticized Devlin's belief that a failure to enforce shared values causes the weakening and decay of society. Hart wrote: "No reputable historian has maintained this thesis, and there is much evidence against it. As a proposition of fact it is entitled to no more respect than the Emperor Justinian's statement that homosexuality was the cause of earthquakes."21 After three more decades of discussion about the prohibition of obscenity and indecency the Mara decision reveals that the law has not even managed to take on board Hart's insight and feminist analysis, while gaining a high profile in the law, has not managed to budge the parameters of the debate.

\section{INSISTING ON REAL HARM IN DEFINING INDECENCY: R. v. JACOB AND THE ONTARIO "TOPLESS STROLl" CASE}

It may be argued that the indecency provision being considered in Mara, as opposed to the obscenity provision being considered in Butler, requires a reference to the community standard and warrants a diminished concern about the harm to identifiable women. The notion of indecency is described in the cases as being constitutively 
contextual and the harm of indecency is more directly related to the ruffling of the sensibility than it is with respect to obscenity. ${ }^{22}$ Much that is not obscene may nevertheless be indecent in a sufficiently public context. Thus, in Mara the actions in question were not objectionable in and of themselves, but become criminal only as a result of their excessively public context. If indecency is directed toward the protection of the privateness of sexuality and some predictable standard of what is appropriate in public, then the community standard of what is too private to be tolerated in public ought perhaps to be more directly consulted. The command of indecency law then is not "Thou Shalt Not," but is rather "Not Here, Not Now." Thus, one might argue that harm to women is less significant in the context of indecency than it is in obscenity, and that indecency does not give rise to the same set of feminist concerns as does obscenity since indecency is, perhaps, merely about protecting a minimum standard of predictability in the public domain.

Thus, the role of the community standard is possibly heightened in the context of indecency since the concern may be to patrol the boundaries of the public/private divide, ensuring that the sexual stays safely at home in the bedroom where it belongs. I want to argue, however, that protection of a predictable zone of the publicly appropriate, understood by reference to a community standard of tolerance, is not a legitimate ground for the prohibition of indecency and ought not to be referred to in defining the scope of the offence. The reasons for its failure as a justification for the offence are precisely the same as the reasons for rejecting Devlin's argument that we can and should prohibit anything that makes the reasonable man sufficiently squeamish. As Hart pointed out (again over thirty years ago), to allow the harmless, but inappropriate, does not destroy society, it merely creates the space for change and perhaps even progress. ${ }^{23}$ Where specific harm to individuals cannot be identified, all we are protecting with the law of indecency is a sensibility. The value of that sensibility has neither been argued for nor proved and the claim that its protection has a significant relation to the stability of society is untenable.

It is interesting in this regard to contrast the Mara decision with the decision of the Ontario Court of Appeal in $R$ v. Jacob, ${ }^{24}$ the now famous "topless" case. In Jacob, the Court found that the accused woman's actions of walking in downtown Guelph without a shirt on did not constitute indecency. The majority of the Court accepted the community tolerance test but found that it ought to be interpreted with strict reference to harm and that, where no identifiable harm had been proved, there could be no offence made out. The Court found that the harm alleged by the Crown was highly speculative. In Jacob, there was a wealth of evidence that the community standard of tolerance had been exceeded by Jacob's actions. Traffic stopped, people pointed, she was told by a police officer to put on her shirt, and children were scurried out of view

Mara, supra note 1 at para. 32.

Hart, supra note 21 at 52 where he writes: "No doubt it is true that if deviations from conventional sexual morality are tolerated by the law and come to be known, the conventional morality might change in a permissive direction.... We should compare such a development not to the violent overthrow of government but to a peaceful constitutional change in its form, consistent not only with the preservation of a society but with its advance."

(1996), 31 O.R. 350. 
by their mothers. Her actions were described as "dirty" and "disgusting" by numerous bystanders and press coverage of the "event" was extensive. ${ }^{25}$ Nevertheless, the Court found, and I think rightly, that Butler imposes a requirement that the Court find specific harm before it may reach a conclusion that there has been a violation of the law. The ruffling of sensibilities here, as dramatic as it was, was not accepted by the Court as a harm worthy of consideration under this rubric. Madame Justice Weiler goes further than the majority in rejecting a focus on the community standard and also explicitly finds that conventional morality is not properly referred to in inquiring into whether an act is indecent under the Code provisions. The rigour of the harm analysis initiated by Butler survives intact in Jacob though not in Mara.

The Jacob analysis is encouraging in its willingness to protect conduct that would be clearly found to violate the Devlinian rationale behind the enforcement of morals. It is encouraging in its willingness to make legal space for that which is both unsettling to the conventional sensibility and disruptive to the public/private split. It is encouraging because it is a rare example of a court - the quintessential static authority - demonstrating trust in society to weather a shock and to ride out a change, to live well in flux. It is encouraging because it reveals the Court genuinely caring about the question of identifiable harm, asking to be shown identifiable harm, and refusing to mobilize the coercive apparatus of the state to protect traditional conceptions of propriety. It is a direct attack on Devlinian reasoning and, as such, it is grounds for a sense of faith in the possibility that the law's power in this area could be of some assistance to progressive causes and that it will not simply slide back into a tool for the enforcement of a static and prudishly masculinist conception of the appropriate.

In Jacob, unlike Mara, the voices of women were not absent. From Jacob's own statement of her refusal to put her shirt back on, to Madame Justice Weiler's insistence that the community standard not be drawn with reference to the sensibilities of the majority we see strongly disruptive voices here that are cause for hope that the law in this area is possibly still salvageable.

\section{Conclusion}

The decision in Mara demonstrates the dangers of putting feminist discourse in place in legal contexts and then abandoning them to misuse by conservative forces, while Jacob demonstrates the possibility of a progressive use of the decision in Butler. Like it or not, Butler exists and cannot be erased. The most appropriate response to it is to attempt, as was done in Jacob, to continue to pull the community standard test away from an inquiry about settled sensibilities and into an inquiry about identifiable harm to individuals, rather than social harm. Whether this will happen again at the level of the Supreme Court of Canada is uncertain. However, what does seem certain is that if feminists abandon this area as a result of the legitimate critique of Butler, the outcome is likely to be more of the same kind of regressive analysis evident in Mara. 